\title{
Political Dimensions of Security Transformation in Latin America
}

\section{Claudio Fuentes}

Abstract This article suggests that the lack of advancement in both the actual protection of citizens' rights and institutional democratic reforms of the security sector in Latin America is due to a complex and intertwined set of political conditions. Three sets of conditions are key: (1) the political context (institutional and political constraints and opportunities); (2) social perceptions and demands on security; and (3) the institutional development of security forces. While policymakers and academics have focused mostly on security institutions themselves, this article argues that they need to be situated within a broader set of incentives and constraints within the political system. The challenge for civil society groups is how to advance a pro-civil rights agenda under such an unwelcoming set of incentives.

\section{Introduction}

Transforming the security sector in Latin America has been one of the most challenging tasks following democratisation in the region. As Chillier and Varela suggest in this IDS Bulletin, after approximately 20 years of democratic rule, institutional reforms of the military and police apparatus have been difficult to implement in certain countries, resisted in others, and left untouched in several cases.

The promise of democratisation did not translate automatically into improvement of material social conditions or protection against abuses by state agents. Indeed, the evolution of political and civil rights in Latin America over the last 20 years does not show a linear relationship between the diffusion of the rule of law and the actual protection of citizens' rights. In this sense, the progressive adoption of international norms since the 1940s, the expansion of advocacy networks since the mid-1960s, and democratisation processes since the 1980s have not automatically resulted in an improvement of the quality of life of citizens living in the region (Agüero and Stark 1998).

According to the Freedom House Survey on political and civil rights, an increasing number of Latin American countries have seen improvements in political rights. From 1976 to 2001, the number of countries where political rights are fully respected increased from four to eleven. However, if we consider respect for civil liberties, which includes protection from the abuse of state power, in 1976 four countries enjoyed full respect for civil liberties, whereas in 2001 only five countries observed a full respect of such rights. In other words, while citizens in Latin America can currently elect authorities fairly and freely, they still suffer mistreatment and abuse at the hands of authorities. Police abuse, discrimination, violence in the streets, and violence at home against women are continuous sources of difficulty within the region.

While new democratic authorities do not illegally detain, torture, or make people disappear, police violence is a daily practice that remains unchecked in several 'democratic' countries (Méndez et al. 1999). This does not signify the absence of change. In fact, some governments in the region have attempted to reform security institutions, provide new legal frameworks to protect citizens' rights, and establish mechanisms of accountability such as ombudsmen and citizens review boards. However, such initiatives have been strongly resisted by security institutions, are difficult to 
implement, or have resulted in increasing the power of those in charge of security issues.

Thus, while social actors are more interconnected locally and internationally than ever in demanding the protection of citizens' rights, certain domestic forces preempt such influence and inhibit substantive changes. Hence we need to observe the conditions inhibiting improvements in human rights and the reform of security apparatuses. What are the factors explaining the gap between commitment to international human rights norms in most Latin American countries and the actual performance of governments in terms of protecting citizens' rights? And why do centre-leftist governments not advance serious institutional reforms of the security apparatus, especially following legacies of brutal military rule?

The lack of advancement in both the actual protection of citizens' rights and institutional democratic reforms of the security sector is due to a complex and intertwined set of political conditions. In the next section, such conditions will be explained along with recommendations for and challenges presented to civil society actors.

\section{Protecting rights in a democratic setting}

Advancing reforms and transformation of the security sector in a democratic setting necessarily requires examining a three-fold set of conditions: (a) the political context (institutional and political constraints and opportunities); (b) social perceptions and demands on security; and (c) the institutional development of the security forces. While policymakers and academics focus on studying and reforming the security apparatus, I argue that we also need to look at a broader set of incentives and constraints within the political system.

\subsection{Political context: institutional and political constraints and opportunities}

Lack of security sector reform in Latin America has been attributable to the strength of the armed forces and the police after transitions to democracy and links with powerful sectors of society. According to this view, violence in Latin America can be explained in part by the uneven distribution of power among those who control resources of power (the means of production, the state apparatus) and the rest of society. For instance, economic elites may influence policymakers to repress workers who are not willing to accept new rules of the game. Those elites may influence policymakers to punish those who attempt to violate private property as well. In this context, security forces - including the police and the armed forces - would carry out their assigned roles by repressing those groups and individuals who threaten the elite.

Even though this structural, power-based analysis highlights an important feature of social relations - social actors' distribution of power it provides an incomplete picture of the problem. Usually, this approach portrays institutions as an equilibrating solution to social actors' conflicting interests; in other words, institutions reflect the power distribution among different groups in society. For example, power-based analyses consider the police to be a reflection of the interests of the powerful. But even though security institutions may reflect an initial distribution of power, they incorporate historical experience into rules, routines and procedures, which persists beyond the initial historical moment and conditions. Moreover, this approach does not explain why some leftist governments that should have incentives to reform previously repressive regimes have not initiated reforms. Governments in Venezuela, Nicaragua, Ecuador, Bolivia, Brazil and Chile have advanced very modest reforms of the security sector. At the same time, in most Latin American countries, intelligence services used by military regimes to repress the opposition have not been reformed, suggesting that there are some areas that democratic authorities are not willing to touch.

The failure to advance reforms is essentially a political problem; thus our analysis needs to include such a dimension. In a democratic setting, incumbents face pressure to simultaneously reduce crime, maintain the stability of the country, and protect citizens' rights. Moreover, governments want to keep themselves in power by advocating policies that are appealing to their electorate, and currently, citizens are very concerned with both the protection of their rights and their protection from insecurity. The story becomes more complex when we observe that in many cases within the region those who control the monopoly of force are linked to criminal networks. So, it is very likely that 
citizens would request, to authorities, hardline policies against delinquents, and by doing so they would increase the power of institutions that are directly involved in such illegal behaviours.

In defining the issue of security, political actors are likely to frame it as a trade-off between liberty and security - between individual rights and security powers (Della Porta 1996).

Politicians tend to see the problem of public safety as a zero-sum game; that is, what citizens gain in security by increasing security institutions powers, they will lose in liberty through the restriction of individual rights.

In this context, two groups are likely to emerge: a pro-order coalition requesting hardline policies in favour of the protection of property and against delinquency, violence and crime, and a pro-civil rights coalition, advocating protection of human rights against state abuses. If the pro-order coalition has the power and ability to frame security threats as a main concern of society, the status quo is likely to prevail. In contrast, if the civil rights coalition has the power and ability to frame the protection of individual rights as a main social concern, then, governments will engage in reforms to transform the police and other security institutions.

In the political arena, we observe these two competing coalitions trying to advance their agendas. The civil rights coalition may include lawyers, human rights organisations, politicians generally identified with liberal and leftist ideas, and some career state officials that are likely to support the notion that every citizen has basic unalienable rights, even in cases in which a society is dealing with crime, terrorism and social disorder. The most active groups are human rights advocacy networks attempting to convince other social and political actors of the need to advance people's rights. Advocacy networks are defined here as organisations characterised by voluntary, reciprocal and horizontal patterns of communication and exchange, including international and domestic non-governmental research and advocacy organisations, local social movements, foundations, the media, parts of regional and international intergovernmental organisations and parts of the executive and/or parliamentary branches of governments (Keck and Sikkink 1998).
The other side of the coin is the pro-order coalition, whose primary concern is the maintenance of social order. In many countries, the police, intelligence agencies, some state officials, more conservative political parties, relevant sectors of the business community and some sectors of civil society tend to champion this view. These actors will seek to provide security institutions with a wide range of legal tools to pre-empt social disorder, terrorism and crime. Those sectors do not reject the existence of individual rights, but they emphasise that such rights should be circumstantial and that authorities must restrict citizens' rights and widen security institutions powers in order to maintain social peace.

The two coalitions are not necessarily unified or highly coordinated, being usually held together by informal ties among actors and groups of society that share a common view. What is important here is the observance of some minimum level of coordination among them. They are generally linked by past experiences and/or membership in specific organisations. Their latent interests achieve greatest coordination in crucial junctures, such as when a case achieves public notoriety or when a prominent bill affecting these groups is debated in Congress.

From a political viewpoint, the pro-order coalition has a comparative advantage over the civil rights coalition. Coordination for the proorder coalition is easier given its prior support from established institutions, such as the police or armed forces. Civil rights groups are less likely to have bureaucratic institutions defending their positions. Bureaucratic institutions, such as the police have comparative advantages over voluntary organisations, because they can use the financial resources they receive to lobby, and the costs of mobilisation are lower than they are for voluntary organisations (Lowery et al. 2002).

Police reforms in Latin America provide concrete examples of how political actors react to security issues. As a government initiates a given reform, police institutions may attempt to influence politicians and the general public, suggesting that any increase in crime is the direct result those 'ineffective' reforms. If the perception of public insecurity rises, governments are more willing to listen to police institutions, increasing 


\begin{tabular}{ll} 
Acting outside the rules & $\mathbf{2 0 0 8}$ \\
\hline Argentina & 37.3 \\
Bolivia & 38.1 \\
Brazil & 28.9 \\
Chile & 48.6 \\
Honduras & 52.2 \\
Mexico & 30.1 \\
Uruguay & 49.8 \\
Latin America Average & $\mathbf{3 8 . 7}$
\end{tabular}

*Latin American Public Opinion Project (LAPOP) survey of 18 countries with selected countries shown here. Vanderbilt University, http://sitemason.vanderbilt.edu/lapop/links (accessed 28 November 2008)

the chances of a restriction in the scope of the reforms and/or a re-establishment of police powers. Because the civil rights coalition has more coordination problems than the pro-order coalition, it is hard for them to articulate an immediate response to this proposed new wave of counter-reforms. Given the inequality of resources of power between these two coalitions, we should expect that even in cases in which governments accept reforms, they tend to be mild and face serious problems in the policy implementation process.

The reform of the police in Argentina is a prime example of such an infrastructure of incentives. When a journalist asked Argentina's former Secretary of Justice and Safety, León Arslanián, whether proposing hardline measures would deliver more votes in an election, Arslanián did not hesitate to respond 'Yes, I believe so'.'

Arslanián led one of the most comprehensive attempts to reform a police force in contemporary Latin America in the mid-1990s. His attempt failed because of the strong institutional and political resistance from a powerful pro-order coalition as well as a simple electoral factor; proposing 'tough' punitive measures against delinquency is a strategy that many politicians are likely to use because citizens are likely to view it favourably. This seems to be the case in many Latin American countries and in democracies in general. Indeed, the French National Assembly adopted a sweeping anti-crime law in early February 2004, giving prosecutors and the police new power to fight organised crime, including the extension from two to four days the period in which suspects can be detained and questioned without charges against them. ${ }^{2}$

So, what explains resistance to change in security institutions is a structure of incentives favouring those who want to maintain the status quo. As 'citizens' safety' is highly valued by policymakers, security forces and their allies in the political system have more room to manoeuvre the policies that are likely to be implemented. Even in political systems that are more favourable to human rights advocacy groups, and even when a 'window of opportunity' to gain allies and influence the policy process presents itself to these groups, the possibilities for successful reform are likely to be counterbalanced by a generally well-organised pro-order coalition. My previous work (Fuentes 2004) suggests that advocacy groups may effectively impact agenda setting in some critical junctures but that their impact on policy implementation and police practices is likely to be, at best, transitory. In sum, the task of enhancing individual rights is extremely difficult given a structure of incentives that favours those who aim to preserve the status quo.

\subsection{Society: protecting personal rights at the cost of violating others' rights}

Politicians respond to their ideals, to political constraints provided by the political system, and to their constituencies. In a democratic context, what society expects from politicians is relevant. 
Table 2 Argentina: Public opinion perceptions of the police, 1991-3

\begin{tabular}{lllll}
\hline & $\begin{array}{l}\text { March/May (1991) } \\
\text { Federal Police }\end{array}$ & Buenos Aires Province Police & $\begin{array}{l}\text { March/May (1993) } \\
\text { Federal Police }\end{array}$ & Buenos Aires Province Police \\
\hline Positive & 27.6 & 25 & 32 & 35.2 \\
Regular & 34.1 & 38.8 & 31.3 & 29.2 \\
Negative & 37.1 & 33.6 & 30 & 32.8 \\
\hline
\end{tabular}

*Surveys conducted by Centro de Estudios Unión para la Neuva Mayoria (CEUNM).

We know that policy decisions do not depend entirely on social perceptions. In other words, policymakers make decisions considering a set of factors, including citizens' perceptions of security.

If security institutions act outside the rule of law as many scholars have documented, we should expect citizens to have a critical view of security institutions. However, this is not what we find in comparative surveys. In general, public opinion surveys across Latin America show higher respect for military and police institutions than for politicians and traditional democratic institutions, such as Congress. ${ }^{3}$

Moreover, when asked whether authorities should respect the rules or act outside the rules, approximately 40 per cent of the Latin American population on average is willing to accept authorities acting outside the rules to control crime (Table 1). It is interesting that even in highly institutionalised countries, such as Chile and Uruguay, a high percentage of the population think that maintaining order should prevail over the acceptance of rules.

A dramatic example of the complexities of citizens' perceptions on security issues can be found in Argentina. Although this country made important legal reforms regarding the protection of individual rights during the 1990s, the actual record of police practices illustrates the difficulties in implementing such rights. Since the re-establishment of democracy in 1983, several international and independent national sources have denounced serious violations of human rights by police forces, focusing on two related illegitimate practices: officers' illegal practices in order to obtain private benefits by using their positions of power - that is, corruption - and practices of violence against the population.
Moreover, several press sources and specialists have revealed the existence of a complex network of illegal businesses led by police officers and political brokers in different districts of Buenos Aires province. This network included profiting from prostitution and illegal gambling, trafficking of stolen cars, kidnapping, trafficking of police reports, and drug trafficking. The network continues to be a 'ladder of illegality' that extends from street-level police officers and districts' political brokers to top-ranking officers, politicians and businessmen (Oliveira and Tiscornia 1998; Dutil and Ragendorfer 1997; Saín 2001).

We should expect that this well-documented evidence would make citizens more supportive of police reforms. Indeed, in relation to the image of the police, citizens in the province show a relatively constant pattern of distrust for the police. Surveys in the early 1990s demonstrate that an average of only 24 per cent of people living in the province have a positive image of the provincial police (Table 2). On average, more than 60 per cent of respondents had a regular or negative image of the police.

In 1996 and in a context of growing public awareness of police scandals, citizens perceived abuses as a structural problem. For instance, 57 per cent of respondents in the capital and the province believed that police abuses were an institutional characteristic of the police, and only 34 per cent considered them to be due solely to individual carelessness. ${ }^{4}$ By the year 2000, 80 per cent of respondents in the Buenos Aires province had a neutral or negative image of the police, while only 16 per cent had a positive image (Catterberg 2000)..$^{5}$ Moreover, surveys conducted by the Argentine Ministry of Justice in the late 1990s confirmed previous trends. When citizens were asked to evaluate police work, more than 


\begin{tabular}{lllll}
\hline & $\mathbf{1 9 9 9}$ & & $\mathbf{2 0 0 0}$ & \\
& Federal Police & Buenos Pires Province Police & Federal Police & Buenos Pires Province Police \\
\hline Do a good job & 36.1 & 35 & 36.7 & 32.5 \\
Don't do a good job & 49.4 & 51.9 & 45.6 & 51.3 \\
Didn't answer & 14.4 & 13.1 & 17.7 & 16.2 \\
\hline
\end{tabular}

*The 1998 survey was carried out on a representative sample of 2001 citizens; the 1999 survey on 5,611; and the 2000 survey on 3,601 interviews (Ministerio de Justicia 2002).

50 per cent of respondents in the province said that 'they don't do a good job' (Table 3).

However, in Argentina citizens are highly divided regarding the trade-off between citizens' rights and public safety. Surveys conducted in Buenos Aires province in 1998 and 2000 show that, despite the fact that citizens tend to have a negative perception of the police, almost half are in favour of giving the police more powers to fight crime. ${ }^{6}$

While 49.3 per cent of respondents from lower classes support increasing powers of the police, middle and upper classes tend to be less supportive of such an option (43.1 per cent). This is consistent with other surveys that show that people from the lower class and with lower levels of education have a better opinion of the police than people from the middle and upper classes with higher levels of education and who are centre-left. ${ }^{7}$

This case demonstrates the complexities of the story of reinforcing the rule of law in democratic contexts. Those who distrust police institutions because they are corrupt or do not perform adequately also suggest increasing their powers.

\subsection{Security sector institutions: legacies and patrimonial incentives}

Another complementary approach toward the lack of change in Latin America is the institutional development of the security forces within the region. Some approaches have argued that the maintenance of certain institutional features characteristic of a military regime have had an enormous impact on issues such as violence (Chevigny 1995; Méndez 1999). In this sense, the military has played a crucial role within society. Examples of such militarisation are the placement of police institutions within ministries of defence in several countries including Brazil, Chile and Colombia, the prosecution of police crimes under special military courts, and the assignment of military officers to police tasks. Moreover, as the police's main task in the past was to defend the regime from 'enemies', national security doctrines blurred the distinctions among criminals, terrorists, political opposition and poor sectors of society (Holston and Caldeira 1998; Neild 2000).

Overall, authoritarian legacies have reinforced repressive and social control functions of the police and weakened the rule of law. Security institutions are often considered to be insulated corporate institutions, resisting any reform attempts (Méndez 1999: 22). Unchecked security forces with inherited institutional and legal privileges from past regimes explain the maintenance of police violence and the resistance to change of security institutions.

A complementary argument suggests another causal mechanism. Here, security officers and incumbents are embedded in unlawful and patrimonialistic behaviour; that is, both public authorities and police officers use their positions and authority to achieve private benefits, creating a complex network of patronage (Hartlyn 1998). Chaotic, violent, and rule-less politics is explained by low levels of civic competence and democratic understanding on the part of mass constituencies and, equally important, high levels of corruption, mistrust, and abuse of power on the part of competing politicians.

One may argue that this is due to a combination of factors such as weak mechanisms of accountability over security institutions, so officers perceive they will not be punished, and 
incumbents not willing to punish abusive police officers given the mutually beneficial relationship between those incumbents and corrupt officers. Thus, the status quo is explained not by the existence of legal provisions allowing police autonomy, but by a given social equilibrium favourable to certain groups of society. The lack of accountability is the mechanism allowing the persistence of such patterns.

\section{Conclusions}

Returning to the central argument, this article suggests that observing political conditions is essential in order to understand why so little has been done in the security sector realm in Latin America. Crucial areas, such as intelligence, police internal affairs, military procurement and military training are untouched areas of reform in most Latin American countries.

I suggest that the combination of a structure of political incentives, as previously described, has inhibited political actors to take action in this relevant sector. Even leftist political sectors are not willing to engage in deep transformations due to involvement with patrimonial institutions, daily demands from civil society to reduce violence by increasing the powers of security forces and electoral demands to control delinquency and crime.

Can civil society do something about this situation? Is there a space for pro-civil rights actors in this story? Latin American countries require more far-reaching and in-depth democratic politics. This includes institutional reforms to make the decision-making process more transparent and to empower citizens; that is, to place citizens in control of what government agencies do (or do not do).

Given the described context, advocacy networks (local and international) can play a crucial role by monitoring security institutions' practices, checking legal procedures and monitoring policy implementation. Advocacy networks are more likely to be influential under the following four conditions: when like-minded groups cooperate with each other to overcome ideological and political differences; when groups gain a positive public reputation; when groups gain allies domestically and abroad; and, finally, when groups are able to mobilise public opinion (Fuentes 2006).
Establishing mechanisms of accountability is an extremely difficult task, even in advanced democracies (Warren 1991). Although security institutions are likely to reject civilian interference in internal affairs, politicians are likely to support such institutions if the population considers that tough measures against crime should be top priority or if there are vested interests between politicians and such institutions. Thus, transforming security institutions does not only depend on proactive activists but on the set of political factors described previously.

Consequently, pro-civil rights groups face several challenges. First, strategies that may work well in an authoritarian context may not be adequate in a democratic regime. Democratic authorities have a set of legal and political tools to pre-empt and respond to criticism domestically and internationally. In general, democratic authorities have depicted allegations of violence conducted by security institutions as the exception rather than the rule. Moreover, authorities are likely to argue that domestic institutional mechanisms will eventually solve misconduct. Advocacy groups - both locally and internationally - have continued to use a strategy that addresses allegations on a case-by-case basis. The experience of Argentina demonstrates that while denouncing specific cases is a crucial strategy in order to gain legitimacy, this should be combined with proposing institutional reforms, because institutional mechanisms to deal with abuses in Latin America are weak and lack both transparency and adherence to basic principles of fairness.

Second, gathering reliable information locally and disseminating it internationally is a crucial strategy in 'making the case' of the need for reform. Advocacy groups can become a relevant focal point for civil rights organisations as well as for public officials if they become good at collecting information.

Third, gaining a better understanding of their political and institutional contexts may help advocacy networks to advance their agenda. Especially if these groups face a well-organised pro-order coalition, they should seek to frame the issue of citizens' rights as complementary rather than detrimental - to the protection of public safety. 
Finally, advocacy networks should improve their capacity to monitor legislative debates and develop alliances with policymakers, the academic community and technical experts to generate a more persistent influence over the policy process. Social actors need to offer plausible policy alternatives and monitor the

\section{Notes}

1 'Conducir no es leer encuestas y correr', Página 12, 6 August 1999.

2 'Lawyers Protest Across France at Sweeping Anticrime Law', New York Times, 12 February 2004, p. A11.

3 The 2008 LAPOP survey (18 countries) shows that the level of confidence in institutions as follows (adding 5, 6 and 7 in a scale from 1 to 7 when 7 means 'A lot'): Armed Forces 55.5 per cent, the President 43.9 per cent, the police 36.3 per cent, unions 25.4 per cent and political parties 21 per cent.

4 Survey conducted by CEUNM based on random representative sample of 1,000 adults. These findings and those reported in the other surveys cited attained acceptable levels of statistical significance. All the surveys were

\section{References}

Agüero, Felipe and Stark, Jeffrey (1998) Fault Lines of Democracy in Post-Transition Latin America, Miami: North-South Center Press

Catterberg y asociados (2000) Percepciones Sobre el Tema Inseguridad en la Provincia de Buenos Aires, Buenos Aires: Catterberg y asociados

Chevigny, Paul (1995) Edge of the Knife. Police Violence in the Americas, New York: The New Press

Della Porta, Donatella (1996) 'Social Movements and the State: Thoughts on the Policing of Protest', in D. McAdam, J. McCarthy and M. Zald (eds), Comparative Perspectives on Social Movements, Cambridge: Cambridge University Press

Dutil, Carlos and Ragendorfer, Ricardo (1997) La Bonaerense. Historia Criminal de la Policía de la Provincia de Buenos Aires, Buenos Aires: Planeta Fuentes, Claudio (2006) 'Advocacy Networks and Police Reform: Assessing their Impact', in Joseph Tulchin and Meg Ruthenberg (eds), Toward a Society Under Law, Baltimore: The Johns Hopkins University Press and The Woodrow Wilson Center for Scholars: 55-89 implementation of policy outcomes. As crime is likely to be a central concern in developing countries, and as citizens are likely to be supportive of a 'tough on crime' approach, the main challenge for local and international advocacy groups today is how to contest the 'iron fist' discourse in new and innovative ways.

carried out in Buenos Aires capital or province or both.

5 Survey conducted by Catterberg and Assoc.

6 Two surveys confirm this trend. In 1998, when respondents were asked whether police forces should have more powers to fight crime, 44.7 per cent supported this claim, while 48 rejected it (survey conducted by CEUNM). In 2000, when respondents were asked the same question, 45.4 per cent supported increasing police powers while 52 per cent rejected it (survey conducted by Catterberg and Assoc.).

7 Surveys conducted between 1998 and 2001 confirm that lower-class sectors have a comparatively better opinion of the police than upper-class sectors. See Centro de Documentación, GEUNM.

Fuentes, Claudio (2004) Contesting the Iron Fist. Advocacy Networks and Police Violence in Argentina and Chile, New York: Routledge

Hartlyn, Jonathan (1998) The Struggle for Democratic Politics in the Dominican Republic, Chapel Hill: University of North Carolina Press

Holston, James and Caldeira, Teresa (1998) 'Democracy, Law, and Violence: Disjunctions of Brazilian Citizenship', in F. Agüero and J. Stark (eds), Fault Lines of Democracy in PostTransition Latin America, Miami: North-South Center Press

Keck, Margaret E. and Sikkink, Kathryn (1998) Activists Beyond Borders: Advocacy Networks in International Politics, Ithaca: Cornell University Press

Lowery, David; Gray, Virginia and Fellowes, Matthew (2002) 'Sisyphus Meets the Borg: Understanding the Diversity of Interest Communities', paper read at the American Political Science Association, 28 August1 September, Boston

Méndez, Juan (1999) 'Problems of Lawless Violence: Introduction', in J. Méndez; G. O'Donnell and P.S. Pinheiro (eds), The (Un)Rule 
of Law and the Underprivileged in Latin America, Notre Dame: University of Notre Dame Press Méndez, Juan; O’Donnell, Guillermo and Pinheiro, Paulo (eds) (1999) The (Un)Rule of Law and the Underprivileged in Latin America, Notre Dame: University of Notre Dame Ministerio de Justicia (Argentina) (2002)

Comparación de Homicidios Dolosos en Países

Americanos, www.jus.gov.ar/polcrim/

Internacionales/Estadisticas2.htm (accessed 2002)

Neild, Rachel (2000) 'Confronting a Culture of Impunity: The Promise and Pitfalls of Civilian Review of Police in Latin America', in A.

Goldsmith and C. Lewis (eds), Civilian
Oversight of Policing. Governance, Democracy, and Human Rights, Oxford: Hart

Oliveira, Alicia and Tiscornia, Sofía (1998) 'Estructura y Prácticas de las Policías en la Argentina. Las Redes de Ilegalidad', in H. Frühling (ed.), Control Democrático en el Mantenimiento de la Seguridad Interior, Santiago: Centro de Estudios del Desarrollo (CED) Saín, Marcelo (2001) 'La ¿Reforma? del Sistema de Seguridad y Policial Bonaerense', Buenos Aires, mimeo

Warren, Christopher (1991) Report of the

Independent Commission on the Los Angeles Police Department, Los Angeles: LAPD 